\title{
Exploring internationalization of Halal Taiwan: analysis of Taiwan's halal food products in Malaysia
}

\begin{abstract}
Taiwan is one of the emerging players in the global halal industry. Since the launching of its New Southbound Policy in late 2016, the country has been aiming to move rapidly into the lucrative global halal markets through its brand of Halal Taiwan. However, thus far, the current state of its halal campaign in the international market is not yet identified. This study intends to fulfill this gap by exploring the internationalization of Taiwanese halal-certified food products that are exported to Malaysia. This qualitative study observed the availability of made in Taiwan halal food products at thirteen supermarkets and convenient stores in Kuala Lumpur and greater Klang Valley in Malaysia, as well as on two major online shopping platforms. The study found that the internationalization strategy of Taiwanese halal food products in Malaysia is characterized by the offering of product variety mainly for impulse purchase with high affordability. However, in terms of number and range of products, as well as the establishment of brand identity, it is found that Taiwan is lacking behind South Korea and Japan. The latter two are Muslim-minority countries that fast becoming emerging players in the global halal market. Implications for policy and managerial practices are also discussed.
\end{abstract}

Keyword: Internationalization; Taiwan; Malaysia; Halal; Food product; Observation; Supermarkets; Convenient stores 